\title{
Displacements and Diasporas
}





\title{
Displacements and Diasporas
}

Asians in the Americas

\author{
EDITED BY \\ WANNI W. ANDERSON \\ ROBERT G. LEE
}

RUTGERS UNIVERSITY PRESS

NEW BRUNSWICK, NEW JERSEY, AND LONDON 
Displacements and diasporas : Asians in the Americas / edited by Wanni W. Anderson and Robert G. Lee.

p. $\mathrm{cm}$.

Includes bibliographical references and index.

ISBN 0-8135-3610-3 (hardcover : alk. paper) - ISBN 0-8135-3611-1 (pbk. : alk. paper)

1. Asians-America-History. 2. Asians-America-Ethnic identity. 3. AsiansMigrations. 4. Refugees-America-History. 5. Immigrants-America-History. 6. Transnationalism. 7. America-Emigration and immigration. 8. Asia-Emigration and immigration. 9. America-Ethnic relations. I. Anderson, Wanni Wibulswasdi, 1937-II. Lee, Robert G., 1947-

E29.A75D57 2005

305.895'07-dc22

2004025322

A British Cataloging-in-Publication record for this book is available from the British Library

This collection copyright @ 2005 by Rutgers, The State University Individual chapters copyright $\odot 2005$ in the names of their authors

All rights reserved

No part of this book may be reproduced or utilized in any form or by any means, electronic or mechanical, or by any information storage and retrieval system, without written permission from the publisher. Please contact Rutgers University Press, 100

Joyce Kilmer Avenue, Piscataway, NJ 08854-8099. The only exception to this prohibition is "fair use" as defined by U.S. copyright law. 